\title{
(IM)POSSIBLE MARTYRDOM: MASCULINITY, AGING, ILLNESS, AND DEATH IN TOMBSTONE AND LOGAN
}

ABSTRACT. The title of this paper alludes to Hannah Arendt's famous claim that in Nazi concentration camps martyrdom was made impossible, for the first time in Western history, by the utter anonymity and meaninglessness of inmates' deaths (Arendt, 2000, p. 133): the paper, in contrast, examines two contemporary films which, while intersecting normative/heroic masculinity with debilitating illness and death, allow for the possibility of martyrdom. Tombstone and Logan, directed by George P. Cosmatos and James Mangold respectively, depict the last days of such pop culture icons of masculinity as John Henry "Doc" Holliday and James Howlett, aka Logan/Wolverine. The films' thematic focus on the (protracted) ending of life, which is evident not only in the storylines and dialogues but also in the numerous close-ups of emaciated, bleeding, scarred and prostrate male bodies, afflicted with tuberculosis and cancer-like adamantium poisoning, invites, first, a discussion of the relationship between the cinematic representations of normative and disabled masculinities. Specifically, since normative masculinity, as opposed to femininity, is synonymous with physical and mental strength, power and domination - including the control of one's own body - the focus of this discussion is if, and how, the films depict Doc Holliday and Wolverine as feminized by their failing/disobedient bodies, thus contributing to the cultural construction of gender. Secondly, the paper discusses the halo of martyrdom with which the films' dying men are rewarded as emotionally deeply satisfying to the viewer: in Logan and Tombstone, death is not averted but hastened for the sake of friendship, family, and the protection of the vulnerable and the marginalized. While the films offer comfort-

1

danij.petkovic@gmail.com 
ing fantasies of self-sacrifice and dignity-restoring death as an antidote to the brutally depicted aging and illness, the last question to be posed in the paper is whether this (im)possible martyrdom reaffirms normative, ablebodied and dominating masculinity.

KEYWORDS: aging, body, disability, femininity, illness, Logan, martyrdom, masculinity, Tombstone.

INTRODUCTION

This paper revolves around three points - normative masculinity; normative masculinity intersected with aging, illness, and dying in the two films under discussion, expressed primarily via feminized bodies of the male protagonists; and (pop culture) martyrdom as the films' response to these anxiety-inducing experiences, which arguably confirms the basic tenets of normative masculinity. While Tombstone and Logan are selected as the representatives of the hypermasculine Hollywood genres (a Western, and a superhero movie which is essentially a Western), and terms such as shot, close-up, and mise-en-scène are occasionally employed in the discussion which follows, the paper does not offer a strictly formal or genre analysis of these films. On the contrary, since my starting point is John MacInnes's "masculinity exists only as various ideologies or fantasies, about what men should be like" (MacInnes, 1998, p. 2, italics in the original), Tombstone and Logan are regarded primarily as visually and emotionally pleasing fantasies about men and meaningful death, which necessarily contribute to "the intensive cultural work that goes into securing masculinity" (Glover and Kaplan, 2009 , p. 88). Though it does not seem entirely justified to, following Laura Mulvey, see film only as "an extension of patriarchal ideology" (MacDonald, 2016, p. 106), it is impossible to deny that "most movies are still decidedly masculine affairs" (Kord and Krimmer, 2011, p. 1), and as such provide fertile ground for the examination of gender representation.

When discussing Hollywood film as cultural work rather than a specific art form, it is nonetheless important to bear in mind, first, its reliance on images, and, second, its well-documented participation in the complex race, class, and gender politics of (in)visibility. On the subject of gender, especially, "[o]ne cannot productively address the productions of men's bodies (masculinized, empowered and superordinated) without also addressing the production and 
the oppression of women's bodies, feminized bodies, queered bodies, and raced bodies (disempowered or subordinated bodies all)" (Thomas, 2008, p. 6). Thomas's words effectively summarize a variety of cultural practices, both discursive and material, from child rearing and fashion to sports and incarceration, but they are invoked here primarily for his emphasis on bodies. While gender in general is "social practice that constantly refers to bodies and what bodies do" (Connell, 1995, p. 71), contemporary normative masculinity, in particular, is a variation on the late eighteenth century "manly ideal" that was centered on "the perfectibility of the male body, which became an outward sign of a man's moral superiority and inner strength of character" (Glover and Kaplan, 2009, p. 89). The discussion of the two films which follows is informed precisely by the awareness of this emphatically visual and bodily character of masculinity. This is why the focus of the analysis is on the films' images of the (sick, aging, and dying) male bodies, on what they look like; what they do; how they suffer; how they are (un)dressed, and how they convey that "[c]ultural associations of disability with dependency, childlikeness, and helplessness clash with cultural expectations of masculinity but overlap with cultural expectations of femininity" (Wendell, 1996, p. 62), resulting in the disconcerting (yet humanizing) feminization of the former icons of masculinity.

While I intend to ultimately take the interpretation of the films beyond gender and towards martyrdom, some additional clarification is perhaps needed on the subject of masculinity. While, after Connell (1995), we know that "there is no such thing as masculinity; there are only masculinities" (Sabo and Gordon, 1995, p. 10), the singular term "masculinity" appears in the title on purpose. It is meant to emphasize that Doc Holliday and Wolverine/Logan, dissimilar as they are, simultaneously deviate from and exemplify what Connell termed normative or hegemonic masculinity - "the culturally dominant ideal of masculinity centered around authority, physical toughness and strength, heterosexuality and paid work" (Pilcher and Whelehan, 2004, p. 83). In Tombstone and Logan, normative masculinity is undeniably the point of departure for these two characters, yet these films exist in the (pop) cultural context in which Doc Holliday and Wolverine have signified normative masculinity for a much longer time, in numerous other incarnations - as heterosexual, able-bodied, intellectually and/or physically superior white men'; "in control of both action and language, the twin domains from which men assert power in a patriarchal cul- 
ture" (Lehman, 2007, p. 12), and in control of their bodies. The last point is especially significant in establishing the difference between masculinity and femininity, and it further supports the thesis that sick/disabled/dying men are necessarily feminized in mainstream cultural products, Hollywood film included. Namely, as Robyn Lonhurst highlights,

"[w]omen are often understood to be in possession of insecure (leaking, seeping) bodily boundaries; in particular they may leak menstrual blood, and milk from their breasts. It is commonly thought that such bodies are not to be trusted in the public spaces of Rational Man. Men, on the other hand, are often understood to have secure (autonomous) bodily boundaries - bodies that are 'in control"'. (Longhurst, 2001, p. 2)

Significantly for some aspects of my discussion of male aging and illness here - their demythologizing/humanizing effect on the hypermasculine (super)heroes in particular - Longhurst immediately adds "In some ways these conceptual codings of bodies have little to do with the actual flesh and blood of women and men" (Longhurst, 2001, p. 2). In a similar vein - though he employs the phallus/penis dichotomy - Peter Lehman interprets the opening scene in Pedro Almodovar's What have I done to deserve this? (1984) as the staging of the difference between the "highly phallic image of powerful, active masculinity" and "the literal male body" (Lehman, 2007 , p. 9). Crucially, it is the "literal male body" with which the woman who is watching "is eventually disappointed" (ibid.). What is so attractive about Tombstone and Logan is precisely this focus on the literal male body that disappoints expectations associated with normative masculinity (which the protagonists, let me emphasize once more, have also signified): here are the bodies that are not in control; bodies that are leaking blood; bodies that fall down, and bodies that are defeated by illness. Yet in this disappointment, Doc Holliday and Logan are humanized, and, simultaneously, martyred, which results in the viewer's profound emotional satisfaction. (The nature of their martyrdom, and the potential causes and implica-

2 This version of masculinity is sometimes dubbed "musculinity" (Kord and Krimmer, 2011, p. 60). Including Doc Holliday among the "physically superior" heroes, next to Wolverine, might seem wrong - but in the context of the films such as My Darling Clementine, The Gunfight at the O. K. Coral, Hour of the Gun (Sturges, 1967) or Frank Laramy's pulp fiction, Doc is a very much able-bodied, if occasionally coughing, hero. (These film versions of Doc are also considerably older than historical John Henry Holiday.) 
tions of this satisfaction, will be addressed in the concluding part of the paper.)

The discussion which follows is thus (uneasily) informed by all these considerations: the representation of the feminized, disempowered male bodies is investigated with the awareness of the underlying cultural assumptions about masculinity and femininity (also, illness and disability); the films' recognition of the temporary nature of normative masculinity - brought into particularly sharp focus via the fact that both the empowered and disabled/feminized masculinities are embodied by the same actors - opens the way for the discussion of martyrdom as the films' preferred way of dignifying the brutality of aging, illness, and dying. This last issue is particularly noticeable in Logan, as the film's considerable poignancy relies on the jarring contrast between the rich visual history of the protagonist's normative masculinity provided by the previous six films, and his 2017 scarred, drunk, and hunched incarnation, on the way to Eden.

\section{"WITHOUT THEM GUNS YOU AIN'T NOTHIN" BUT A SKINNY LUNGER": TOMBSTONE}

George P. Cosmatos' 1993 Western is named after a small Arizona town - "just another mining camp" calls it contemptuously at one point - in which the (in)famous 1881 shootout at the O. K. Corral took place. The film focuses on the events leading to, and following, the shootout, including the Earp Vendetta Ride, and Doc Holliday's death in Colorado, six years later. The gunfight itself - extensively mythologized and sanitized in classical Hollywood and television (Tombstone, the Town Too Tough to Die (McGann, 1942); My Darling Clementine (Ford, 1946); The Life and Legend of Wyatt Earp (1955) and Gunfight at the O.K. Corral (Sturges, 1957), to name just a few) - happens in the second hour of the film, and it is rendered more or less realistically, as a messy two-and-ahalf-minute long affair which results in three dead bodies. Yet among all the noise, dust, and confusion, there is time for Doc Holl-

All quotations are from http://www.script-o-rama.com/movie_scripts/t/ tombstone-script-transcript-val-kilmer.html.html, occasionally, I will refer to Kevin Jarre's original screenplay as well: http://www.imsdb.com/scripts/ Tombstone.html. 
iday to be shown firing from an empty pistol. "I've got you now, you son of a bitch", his opponent, Frank McLaury (Robert John Burke), proclaims. "You're a daisy if you do", Holliday replies and raises both his arms in a mock-Christ-like gesture of surrender. Having shrugged off his long coat at the beginning of the shootout, he is wearing only a pair of black pants and a white, sweat-drenched shirt, both of which accentuate his thin figure; visibly pale under the Arizona sun and held at gunpoint by the man who intends to kill him, at one of the most celebrated moments of heroic masculinity, Tombstone's Doc Holliday embodies illness, vulnerability, and ironic amusement at the prospect of his own death. The next second, however, he fires his other gun and kills McLaurie instantly. This seems to be the accurate summary of how Doc Holliday is depicted in Cosmatos' film - ill, ironic, and deadly. The "ill', in particular - the focus of this analysis - is not merely ornamental. While the earlier/other film and TV versions tend to downplay or virtually erase ${ }^{4}$ the illness the Georgian dentist died of, in Tombstone the progression of tuberculosis is inseparable from the unraveling of the plot - as the film ends, Doc's life ends as well. Indeed, Doc's first appearance shows him playing poker in a Prescott saloon and coughing sporadically ${ }^{5}$; the last one, at the end of the film, shows a pale, barely speaking Doc lying in bed in Glenwood Sanatorium, saying goodbye to Wyatt Earp (Kurt Russell), and shedding a tear in an extreme close-up. Even before Doc appears, the narrator, Robert Mitchum, introduces him in a voice-over at the very beginning of the film as 'Earp's friend, John 'Doc' Holliday, a Southern gentleman turned gunman and gambler, [who] also travels West, hoping the dry climate will relieve his tuberculosis". Thus Tombstone's Doc Holliday is inseparable from his illness, and Cosmatos makes it abundantly clear, not relying on dialogue merely to convey that

4 "Erase" does not necessarily mean that the earlier film versions made Doc Holliday healthy - this, incidentally, is the option Emily Andras chose for her 2016 supernatural TV show Wynnona Earp - it means that Doc's illness is acknowledged by an occasional cough, but never shown as explicitly as in Tombstone. Even in later, more realistic versions, such as Lawrence Kasdan's Wyatt Earp (1994), Doc Holliday (Dennis Quaid) never faints, though obviously ill; his last days, moreover, are never depicted and his death is merely mentioned in the closing credits - a short text rather than a long series of scenes and images as in Tombstone.

5 Kevin Jarre states in the original screenplay, "Doc has such unerring style and aplomb that he makes his constant tubercular coughing sound as if he's merely clearing his throat". As with all the other instructions, Val Kilmer delivers. 
Doc suffers from a progressive lethal condition ${ }^{6}$, but consistently shooting Val Kilmer pale, with red-rimmed and/or dark-circled eyes; always with a sweaty face; more often than not drunk ${ }^{7}$; coughing, and several times coughing up blood ${ }^{8}$; fainting; occasionally only half-dressed and bedridden. Kilmer's figure, too, fits the very first description of Doc Holliday in Kevin Jarre's screenplay: "as thin as a reed". Just before the $\mathrm{O}$. K. Corral fight, moreover, he is depicted using a walking stick, the image calling attention to one of the lesser-known aspects of tuberculosis, its propensity to spread to bones, joints and spine, causing bone pain, swelling and even late onset paraplegia.

It is against this always-present, overwhelmingly physical reality of illness that the issues of gender and martyrdom are played out on Tombstone's Doc Holliday. Leaving the martyrdom for the concluding part of this discussion, I want to focus on the film's take on Doc Holliday's masculinity first. In both mainstream Hollywood and the historical and cultural context of the nineteenth century US that Tombstone (re)creates, the pale-faced, bleeding and fainting, thin body, on two occasions utterly passive in the arms of strong(er) men who carry it, will inevitably appear feminine. The impression of such femininity is further strengthened by Kilmer's languid movements (the screenplay explicitly states that Doc has "feline grace", and Kilmer delivers); by Holliday's elegant clothes paired with his elegantly ironic, educated language that set him even further apart from the other male characters; and a remarkably handsome face, often in close-up, characterized not only by paleness but by full, luscious lips as well. Moreover, while always-

6 Though the dialogue is additionally brilliant: in the death-bed scene in Glenwood Sanatorium, Wyatt asks Doc - "How we feelin' today, Doc?", to which the former dentist replies, feebly: "I'm dying, how are you?"

7 Historical Doc Holliday was, in fact, addicted to both alcohol and laudanum (Tennant, 2015). In Tombstone, laudanum is associated with women (Wyatt's wife, Mattie Blaylock, primarily), while Doc relies exclusively on (manlier) whiskey.

8 The progression already alluded to is observable in the representation of blood as well. In the first scene where coughing up blood is introduced, Doc wipes his mouth with a white handkerchief, insists that he is "right as the mail", and then faints; in the last scene, it is during Wyatt's Vendetta Ride (his "reckoning"), that Doc, fainting after a bout of coughing, slides off his horse with the clearly visible, ample amount of blood around his mouth. His unconscious body is carried not by one, but two men: Texas Jack Vermillion (Peter Sherayko) and Wyatt Earp. 
present and physical, Doc's illness and suffering are also, for the most part, highly stylized: unlike Mangold's Logan, Cosmatos' Doc Holliday suffers prettily. In the cultural context in which prettiness is expected of young girls, Doc Holliday is capable of fine irony while held at gunpoint; he flirts in perfect Latin while drunk; faints gracefully, and dies peacefully in bed, instead of choking on his own blood, which was the usual outcome of tuberculosis. In a Western littered with corpses of men who die from bullet wounds, Doc's death thus stands out as feminine as well. The way Tombstone handles it, this death comes closer to the sanitized and sanctified death of Helen Burns in Jane Eyre (Tankard, 2018, pp. 63-9) than to the death of the historical John Henry Holliday - though, of course, this paper is not about the historical person but a specific film interpretation of him 9 .

But the film does not portray Doc Holliday only as feminized by his illness; on the contrary, it heightens productively the tension between the disabled/feminized and "enhanced"10, heroic masculinity. In Tombstone, Doc Holliday is not only an emasculated TB patient, a pretty pale face and a suffering body in elegant clothes: he is also, indubitably, one of the fastest and deadliest killers in the West. Fittingly, Holliday's masculinity is enhanced with that quintessential symbol of Western manliness, guns, to such a degree that Ed Bailey (Frank Stallone) insults him by saying "Without them guns you ain't nothing but a skinny lunger" [the late nineteenth century slang for a person suffering from tuberculosis]. The film's simultaneous emphasis on Holliday as feminized by tuberculosis and Holliday as the icon of violent/heroic masculinity results in a strange blend of realism, (re)mythologization and stylization in relation to both gender and illness. On the one hand, Tombstone demonstrates, in various scenes and shots, that "to be consumptive is to be vulnerable, impoverished, desexualized, silenced, and generally disempowered" (Tankard, 2018, p. 15) - i.e. like a woman, especially, but not only, in the context of the nineteenth century US. On the other, it points to masculinity that lies almost exclusively in

9 Needless to say, a whole new paper could be written on the subject of Tombstone's deviations from historical facts, especially in relation to the legal status of both the O.K. Corral gunfight and the Earp Vendetta Ride, and the relationship between Wyatt Earp and Doc Holliday.

10 I am borrowing the word from James Mangold's Logan: "enhanced" is the term Donald Pierce (Boyd Holbrook) uses to refer to his prosthetic hand, and to Wolverine's adamantium-fortified skeleton and claws. 
enhancement and performance, and is no less deadly for it. When Ed Bailey insults Doc in the Prescott saloon, Doc puts his guns on the table, mockingly, to prove that he does not need them to be a man: moments later, however, he will kill Bailey with a hidden Bowie knife. Their short exchange and the resulting death convey that " $[\mathrm{m}]$ asculinity is not a collection of attributes possessed by a male subject from birth but a set of expectations that society deems appropriate for a male subject to exhibit" (Gates, 2006, p. 28). While masculinity may not be located in the guns specifically, it is about asserting control and domination, through violence if necessary (and in a hypermasculine film genre such as Western, it usually is). It is thus tempting to read Doc's near-perpetual ironic smirk as expressing his awareness of the gap between the "highly phallic image of powerful, active masculinity" that he projects/performs, and his "literal male body", which, as Lehman insists, necessarily disappoints - the awareness which his illness sharpens into particular intensity.

In its treatment of male illness, Tombstone, moreover, does not remain limited to the necessarily disappointing aspects of a nonenhanced, non-performing male body. The strange semi-realism of Cosmatos's film is evident in details suggesting the socio-economic aspects of male illness as well, as Doc Holliday's suffering/enhanced body does not exist in a vacuum, but in a specific cultural and social context that determines the expressions and reception of both masculinity and disability. If, throughout the nineteenth century, as Alex Tankard points out, to be consumptive is to be impoverished, the film suggests it from the very first minute, in the Robert Mitchum narrated introduction which identifies Doc as "the Southern gentleman turned gambler" [italics added for emphasis]. As is widely known, it was with the onset of illness that Doc stopped practicing dentistry, lost his livelihood and became a professional gambler and a gunslinger, existing on the margins of society, moving from one hotel room to another, and finally dying in one, contrary to Tombstone's romantic rendition. To be consumptive, moreover, meant to be isolated, too, not necessarily because of the infectious nature of tuberculosis, but on the basis of gender, as "invalidism of any sort isolated a man from the collegiality of other men. Men thought it unmanly to be ill and did not want to be around other men during illness. An ill man was likely to suffer ostracism from other men" (Ott, 1996, p. 76). One of the reasons why Doc's motivation for joining Wyatt Earp's Vendetta Ride - that Wy- 
att Earp is his friend - appears so plausible in Tombstone is that Wyatt, and the Earps in general, do not shun or ostracize Doc for his illness, though the derogatory term "lunger", heard several times in the film in relation to Doc, points to the already changing cultural climate regarding tuberculosis. Namely, from a romantic illness associated with artistic creativity (Sontag, 2001; Tankard, 2018), near the end of the nineteenth century tuberculosis was already beginning to be seen in a more negative light ${ }^{11}$.

Tombstone, thus, does not shy away from demonstrating that tuberculosis strips a man of physical strength, transforming him into a "skinny lunger" in need of enhancement; it also suggests the sick man's state of isolation from his peers and his difficulties in reaching financial independence - indeed, the film shows that "tuberculosis [...] feminized a man, both through connotation and through consequence" (Ott, 1996, p. 76). In this context, it is worthwhile to examine the interplay between masculinity, illness, and sexuality in Cosmatos' film, as normative masculinity, which Doc both exemplifies and deviates from, relies on heterosexuality as one of its constitutive elements. On the one hand, Doc's heterosexuality is never in question - in fact, in his very first appearance in the Prescott saloon, Big Nose Kate (Joanna Pacula) sits in his lap and he exclaims in mock horror, "Kate, you're not wearing a bustle, how lewd!", demonstrating publicly - before other men - his familiarity with the woman's body, with and without the bustle (also, his familiarity with, and the lack of respect for, sexual decorum, resulting from his illness-related social marginalization). Yet it is interesting to note that in this scene, in his very first appearance, Doc is sitting in front of a mural depicting a giant female nude, which is the position that might suggest his feminization. In a different scene, Kate herself states, equally publicly, that "Doc can go

11 On the subject of the Earps' enlightened treatment of Doc Holliday, however, one has to bear in mind that the film depicts the events which took place in the 1881-2: it was in 1882 that Robert Koch's made the now famous "announcement that Mycobacterium tuberculosis was the communicable agent responsible for most cases of tuberculosis in human beings" (Tankard, 2018, p. 17), though the full implications of the discovery, resulting in institutionalized isolation of the sick, were realized only at the beginning of the twentieth century (ibid.). Thus the Earps not shunning or ostracizing Doc may, to a certain degree at least, be attributed to their incomplete knowledge of the illness itself. On the other hand, Doc is visibly ill, and the Earps, whether or not they are familiar with the mechanism of TB infection, are remarkably friendly - Wyatt, in particular, is depicted as both openly affectionate and fiercely protective of Doc. 
on day and night, and then some", ostensibly referring to poker, but the sexual innuendo is clear, especially when she immediately adds, "That's my loving man". Rather than showing Doc as sexually incapacitated by his illness, the film thus seems to be conforming to the popular stereotype regarding the insatiable sexual appetite of the people suffering from tuberculosis ${ }^{12}$. (Needless to say, the reality of illness is quite different, as more often than not, tuberculosis results in both male and female sexual dysfunction (Kulchavenya et. al. 2017).) In the first of the three scenes in Tombstone in which Doc Holliday is depicted as bedridden, moreover, Doc explicitly tells Kate that they have to "redefine the nature of [their] association", confirming that said "association" is primarily sexual. The desire for change is initiated by Doctor Goodfellow informing Doc that his "condition has quite advanced", and that he has lost $60 \%$ of his lung tissue, "maybe more". In order to live for "2 years or 2 days" more, Doc, quite in keeping with the nineteenth century medical views, is advised by the doctor to "deny his marital impulses"13. Performing normative masculinity which is characterized by a healthy (hetero)sexual appetite, Doc replies, "Get out of my sight". Immediately after, however, in private, he informs Kate of the change that is needed in their relationship: at this point, before the murder of Morgan Earp and the Earp Vendetta Ride, Doc Holliday apparently wants to live. Kate's response is to move her hands over his prostrate body, ending at his crotch, and to put a cigarette between his lips before continuing with her ministrations. Even though Kate insists on being "a good woman" to Doc, the scene inverts traditional depictions of male and female bodies, and masculinity and femininity on film. It is Kate who is active, moving, then sitting; fully dressed; putting a phallic object in Doc's mouth; demanding and initiating sex. Doc is lying in bed, dressed only in a sleeveless white shirt which exposes his naked arms and throat an object to be looked at and "pawed at", thus virtually a woman.

Yet, despite being sexually objectified, Doc Holliday is heterosexual - it is, after all, his heterosexuality that is reaffirmed in the

12 The link between supposed hypersexuality and tuberculosis was so well-established that, as late as 1960, "an expert witness at the Lady Chatterley trial declared of D.H. Lawrence's novel that "[s]adly but truly, perhaps only a dying consumptive could have written such filth"' (Tankard, 2018, p. 72).

13 One has to wonder whether this particular piece of advice was motivated by the concern for the patient, or the eugenic tendencies so prevalent in the AngloAmerican world in the last decades of the nineteenth century. 
scene just recounted, as he finds it impossible to refuse sex with a woman. This, however, does not mean that he is not feminized in Tombstone in yet another way, in addition to the illness affecting both his socio-economic position and his appearance, as already discussed. The feminization is to be found in Cosmatos' and Jarre's romanticizing the relationship between Wyatt Earp and Doc. The characterization, dialogues, and filming/framing suggest that Doc is indeed playing the role of a woman to the normative masculinity so unambiguously embodied in Kurt Russell's Wyatt Earp. In the director's cut of Tombstone, for instance, when Morgan Earp (Bill Paxton) is murdered by The Cowboys, Doc Holliday's response is both conspicuous and quite telling. While fully aware of what has happened, Doc does not even attempt to offer consolation to Wyatt: sitting in a chair in his hotel room, sweaty, pale, and drunk, he is reciting Kubla Khan - "Weave a circle round him thrice/ And close your eyes with holy dread...". (Coleridge's lines serve to prophesize the transformation that will happen to Wyatt, resulting in the merciless Vendetta Ride.) Wyatt's obvious romantic interest, Josephine Marcus (Dana Delany), conversely, runs to comfort Wyatt and gets yelled at. In the morning, Doc will join Wyatt on his way to the train station, silently but undoubtedly standing by Wyatt's side while Wyatt, taunted by The Cowboys, is seeing off his brother's coffin and the rest of his broken family away from Tombstone. In both of these scenes, it is clearly Doc, and not Josephine or Mattie, who exhibits the behavior of a knowing lover or a supportive wife rather than a friend: later, he will lend Wyatt his more masculine services as a gunman, too, but the masculinity seems secondary in comparison with the loving and supportive nature of Doc's serving. As women are eliminated from the scenes that follow - there is only one brief encounter between Wyatt and Josephine at Hooker's ranch before their reunion at the very end of the film - this interpretation of Doc's and Wyatt's relationship is further emphasized. Indeed, Doc's unusual attachment to Wyatt is explicitly commented upon by Kate who, while Doc is saddling his horse to join Wyatt in his crusade, yells: "Why? Why is he [Wyatt Earp] so much?"14

14 While Tombstone undeniably romanticizes Wyatt's and Doc's friendship, at least some of it is historically accurate. Bat Masterson, for instance, claimed that "Doc had but three redeeming traits. One was his courage; he was afraid of nothing on Earth. The second was the one commendable principal in his code of life, sterling loyalty to friends. The third was his affection for Wyatt Earp". http://www.tombstonetimes.com/stories/facts.html, 7/14/2018 
The Kubla Khan and Kate yelling scenes appear only in the director's cut of the film, released in 2002, nine years after Tombstone was made. Even without them, the official version offers ample evidence that Wyatt and Doc are effectively depicted as a stereotypically heterosexual couple, and not necessarily as two male friends or even as a homosexual couple, as the film does offer gay representation in the characters of Billy Breckinridge (Jason Priestley) and Mr. Fabian (Billy Zane). In the eloquent shot just after the gunfight at O.K. Corral is over, for instance, Doc is shown standing still, waiting wordlessly for Wyatt to join him, so that he can fall into step beside Wyatt. Yet far from suggesting their equal, masculine status, the scene emphasizes Doc's femininity in relation to Wyatt's normative masculinity - filmed from the back, Wyatt is characterized by his long, flowing black coat and a long-barreled gun in his right hand, whereas Doc, walking beside him, presents a slim, white-shirted, coatless figure. Moreover, in one of the most romantic scenes in the film, Doc is depicted lying in bed, dressed in white, crying and physically fragile, conforming to the nineteenth century and Hollywood conventions of both femininity and "consumption", whereas Wyatt is physically strong, fully dressed, and standing up/sitting down. The scene takes place during the Earp Vendetta Ride, on Hooker's ranch. (Hooker is portrayed by another Hollywood icon of normative masculinity, Charlton Heston.) Having fainted after a coughing and blood-spitting fit, Doc is carried in the arms of Texas Jack Vermillion and Wyatt Earp; Wyatt, moreover, is briefly shown cradling Doc's head and wiping the blood off his mouth. The friendly rancher provides them with a place to stay for the night, at great personal risk. The next scene shows Doc shivering audibly in Hooker's guest room, in a white shirt partly open to reveal his chest; the shirt sleeves are short and his bare wrists and hands are clearly visible - without cards or guns, they convey Doc's feminine-coded vulnerability. Camera lingers on his exceedingly pale, sweat-drenched and (still) very handsome face. As it moves back to encompass the whole room, it becomes obvious that it is not only the viewer that watches Doc. Head propped on a white pillow, body laid out on white sheets, covered by a white coverlet, Doc is, in fact, gazed at by at least four fully-dressed and armed men, Hooker included. The scene powerfully conveys the feminization of the ill male body - which is depicted as bridal, almost - and the normative, phallic masculinity premised on control over body and conveyed via clothes and upright posture. After the agonizing 
day, at dusk, fully clothed, armed, and erect Wyatt Earp and whiteclad, prostrate Doc Holliday have a conversation which, conveniently for Wyatt, centers on Johnny Ringo's innate psychological deviance rather than the Earps' responsibility for the O.K. Corral. "A man like Ringo ... got a great empty hole right through the middle of him. He can never kill enough or steal enough or inflict enough pain to ever fill it", Doc explains. The conversation ends with Wyatt's acknowledgment that he "can't beat him [Johnny Ringo]", though he is about to meet him in a duel. Having confirmed this - essentially a death sentence for Wyatt - Doc attempts to get up from the bed and falls back onto the pillows, bent over by a coughing fit, fingers clutching a white handkerchief. "Oh God...I'm sorry, Wyatt", he breathes out mournfully, not trying to negate he is in pain, though later he will dismiss it as "pretending". Pointing at the sheriff's badge on Wyatt's chest, he adds, "What's it like to wear one of those?". Wordlessly, Wyatt unpins his badge, and presses it into Doc's pale, unadorned, fragile hand. The shot of their two hands clasped together for a moment, over a sheriff's badge, is arguably one of the most romantic images in the whole film ${ }^{15}$. There is added poignancy in Wyatt's barely walking after this exchange, and looking in the direction of Doc's bedroom while getting on his horse. Hooker reassures him, "Don't worry... they want him, they gotta come over us first". Doc is obviously positioned as a damsel in distress, a blood-spitting Sleeping Beauty who will be defended by the masculine gunmen-knights. And it is his illness, and Wyatt's care for him, that position him like this.

The final, death-bed scene amplifies the feminine-coded vulnerability and the physical frailty of the dying man. In Glenwood Sanatorium, Wyatt walks in on Doc being given last rites by a priest, which Doc, no longer able to sit up or raise his voice, ironically describes as "investigating the mysteries of the Church of Rome". Wyatt attempts to make him play cards; the former poker player refuses and opts for a barely breathed, broken speech that, in a profoundly unmasculine manner, focuses on love. Doc's last words appeal to Wyatt's feelings, too, motivated by the unstated but obvious

15 Jarre's original script goes even further: in the scene which was never filmed, after Wyatt discovers that Doc has managed to get out of bed and kill Johnny Ringo for him, he notices that Doc is wearing his badge. When Doc admits "I just wanted to see what it felt like" and starts unpinning it, the script states that "Wyatt stops him, pressing his palm onto the badge over Doc's heart" (http:// www.imsdb.com/scripts/Tombstone.html). 
desire to spare his friend the sight of dying - "Wyatt? If you ever were my friend... if you ever had even the slightest feeling for me... leave now. Leave now". Seeing that Wyatt is reluctant to go, Doc opts for small, almost child-like "Please?" at the end. Wyatt leaves, and Doc sheds a tear in extreme close-up. Moments later, he dies in the sanatorium bed, aged 36, looking at his bare feet and commenting, "This is funny". Instead of dying in his boots like a "real man", which he hoped for - the bare-footed-this-is-funny detail in Tombstone is historically accurate - Holliday dies in a hospital bed, in tears, killed by a debilitating, emasculating illness rather than a bullet. The illness, moreover, was presumably inherited from his mother Alice, which only reinforces the feminizing associations of consumption; while Tombstone does not insist on it, it is a wellknown fact, silently underpinning every instance of Doc's coughing and fainting.

\section{"PEOPLE SAID SOMEONE WHO LOOKED LIKE THE WOLVERINE WAS IN EL PASO, DRIVING. SAID HE LOOKED OLD": LOGAN}

James Mangold's Logan (2017) foregrounds male aging, illness, and dying via the titular character played by Hugh Jackman, and, to a lesser degree, by Patrick Stewart's Charles Xavier; the martyrdom theme which they both share is further amplified by Caliban's (Stephen Merchant) sub-plot. Unlike martyrdom and dying, moreover, growing old and dying are not necessarily connected: the crucial aspect of the plot is that Logan, like Doc Holliday, appears to have a chance to live a bit longer. "You still have time", Charles Xavier reminds him at the Munson farm; the kind doctor at the walk-in clinic near the end of the film echoes this, claiming Logan needs "rest and treatment". But, as Mangold's film is a Western in a superhero movie costume, what the viewers witness instead is Logan speeding up his death, just like Doc Holliday, literally running to it in his final fight against evil, which is, fittingly, an American army-funded biomedical corporation experimenting on mutant children in Mexico.

Like Tombstone - the film, and Jarre's script in particular - Logan is invested in demythologizing and humanizing pop culture icons of masculinity, mostly by stripping them of their respective attributes of normatively masculine and/or superhuman power. Like 
Tombstone, moreover, which acknowledges the pauperizing effects of male illness in the nineteenth century US, Logan, especially in the first half, firmly situates its protagonist on the losing end of the near-future neoliberal economy. In the first few minutes of the film, the viewers are presented with the former X-Man who is not only visibly old, ill, and drunk, but also struggling financially. The film takes place in 2029: both tigers and mutants are apparently extinct, and the mutant once known as Wolverine is a shabby limo driver working between El Paso and Juárez, under the name James Howlett. The short sequences depicting "Mr. Howlett"'s clients convey the bleak landscape of inequality that "Old Man Logan" futilely tries to navigate - entitled businessmen in cowboy hats who use the word "kill" to talk about a successful business trip on a cell phone; white college boys screaming "USA! USA! USA!" drunkenly while returning from Mexico; drunken bridesmaids in pink flashing "the driver" for fun and titillation (their own). Logan dreams of buying a boat, the symbolically titled Sunseeker, while trying to earn the impossibly huge sum of $60,000 \$$ on his low-paying job, in a gig economy dominated by multinational corporations, two of which - Alkali Transigen and Canewood Beverage - feature prominently in the film. Logan is also hiding, and taking care of, 90-year-old Charles Xavier in an abandoned smelting plant in Mexico, just south of the US border, with the help of an albino mutant named Caliban (significantly, although he is played by much younger Stephen Merchant, Caliban is described in the script as a man in his sixties). Just as Wolverine is apparently stripped of his legendary powers, Charles Xavier, too, is no longer respectable Professor X, housing School for Gifted Youngsters on his enormous New York estate, but an old man suffering from Alzheimer's - "a degenerative brain disease in the world's most dangerous brain, what a combo", as Dr. Rice (Richard E. Grant) puts it. "The world's most dangerous brain", moreover, is not an exaggeration, as the viewers learn that Charles's brain has actually been classified by Homeland Security Act as "the weapon of mass destruction". The classification explains the trio's hide-out in Mexico and suggests the governmental, in addition to corporational, abuse of those who are different, which is the theme X-Men movies, the original trilogy in particular, are rightly famous for. (As the film progresses, it turns out this classification is sadly accurate: not only does Charles cause several lifethreatening incidents when experiencing seizures, he is also revealed to have been responsible for the death of seven unidentified 
X-Men in 2028 - hence Logan's desire to relocate him onto The Sunseeker in the middle of the ocean.) The three surviving mutants, all disabled and in need of medical assistance - a telepathic Alzheimer patient in a wheelchair; an albino with severely restricted mobility, and the middle-aged man $^{16}$ who exhibits unmistakable cancer-like symptoms - are not only socially marginalized and financially struggling, but also without medical help, as institutionalized medicine is inseparable from government surveillance: it is in the first few minutes that we also see Logan buying medicine from a paramedic in front of a hospital. The medicine, it is later revealed, is just regular ibuprofen, and it is reserved for Charles, as Logan self-medicates with alcohol. In addition to American biomedical corporations hiring mercenaries, experimenting with legally non-existent children, and cooperating with food industry to control the population, this (lethal) utilization of medicine for surveillance is the most socially conscious moment in a film full of such moments and insights.

Logan's social commentary, unusual for both Westerns and superhero movies (but more than welcome), is fused with Mangold's poignant, occasionally humorous, examination of heroism, parenting, and martyrdom, which becomes more and more pronounced as the film progresses, culminating in Logan's Christ-like death in Eden ${ }^{17}$. Whatever its other themes are, however, the film has a high

16 Of course, Logan - James Howlett - is much, much older: canonically, he was born in the late nineteenth century. Due to his mutations, including the ability to regenerate quickly, and the secret experiments conducted in the Weapon $\mathrm{X}$ program which resulted in his skeleton and claws being fortified by adamantium, he has been able to live a very long life without aging significantly - until this film.

17 Logan is approached by a Mexican woman (Elizabeth Rodriguez), who offers him $50,000 \$$ to drive her and a little girl, Laura (Dafne Keen), to a location in North Dakota; refusing at first, he later relents, mostly because he needs the money for The Sunseeker, and agrees to take them. The woman, Gabriela, is killed; Logan, Charles, Caliban and Laura are attacked by the Transigen's hired guns, led by the "enhanced" Donald Pierce; Caliban is captured leaving the trio to embark on a journey to North Dakota, to the place called Eden, with Pierce's mercenaries at their heels (they torture Caliban into tracking his friends; he finds revenge and redemption by blowing them up, and himself, later on). The girl, Laura, is revealed to be Logan's biological daughter, if biological is the right word to use to refer to Logan's being reduced to "source DNA" in Transigen experiments, while her mother is an anonymous Mexican girl, one of those girls who raised "the experiments" in their bellies for the company, and who "no one can find any more". The father and daughter share not only genetic material, but also abuse 
body count and is undeniably centered on death, violent and otherwise. And while no outline can possibly do justice to the actors' delivery and the cinematography - the lighting and mise-en-scène in the smelting factory scenes, for instance, resemble a Rembrandt painting; Caliban is explicitly modeled after Munch's Scream; the film's aesthetic slips effortlessly between genres, from a gritty action movie to melancholy film noir and denim-and-blood-colored Western and road movie - they are employed, primarily, to convey and complement the film's de- and re-mythologizing approach to the superhero's aging, illness, and dying. The film ends with the comic-book image of Logan's grave in Eden, having confirmed his

at the hands of army and medical professionals: having the same mutations as Logan, Laura was submitted, at the age of 11 , to the same excruciating adamantium-enhancement procedures as he was. The girl, moreover, is legally the property of Transigen: she was stolen by Gabriela, who worked there as a nurse, when the program was terminated and the mutant children started being "put to sleep". Several heroic nurses, including Gabriela, tried to save as many children as they could, agreeing to meet in Eden. Eden, it turns out, is the place which exists only in the X-Men comics that both Laura and Gabriela are fans of, but, as Charles insists, "it's real for Laura", effectively forcing Logan to continue driving them to the location even after this discovery. On the way to non-existent Eden, in a nod to Shane, "the Howletts", make a short stop at the farm of a friendly, deeply Christian Munson family. The pleasant visit, which Charles intends as a lesson for both Logan and Laura in "what life looks like ... a home, people who love each other", ends in a massacre, as it is here that the new mutant, a grownup replica of Wolverine called X24 (also played by Jackman) is unleashed for the first time by Transigen men catching up with "the Howletts". X24 kills the Munsons and Charles in his bed; it is he who will kill Logan, too. After burying Charles in the place where "there's water", the choice which painfully echoes their dream of living on the ocean aboard The Sunseeker, Logan and Laura continue their journey to Eden. (Un)surprisingly, the coordinates lifted from a comic book prove real enough as Laura finds a group of her fellow mutant children from Transigen. Here, Logan gets his final, much-needed rest, and a make-over: while he is sleeping, the children give him a haircut and stylize his beard to make him resemble his legend, the comic-book Wolverine. After two days in Eden, Logan is killed in the final battle with the Transigen mercenaries, protecting the children. After a long and savage fight, X24 impales him on the tree trunk. Dying Logan is addressed by crying Laura as "Daddy", and finds time to deliver the crucial (impossible?) imperative for anyone victimized by the powerful institutions or individuals: "Don't be what they made you". The last scene depicts Logan being buried by the mutant children; over his grave, Laura delivers Alan Ladd's final speech from Shane - which she sees with Charles for the first time in a hotel room, and which functions throughout Logan as a leitmotif about the man/hero not being able to change who he is - and, after her friends have left, lingers long enough to transform the cross made of sticks into an X sign. The very last image in the film is Logan's grave, a comic-book pile of stones and a makeshift sign of the now non-existent X-Men, the family to which Logan once belonged. The mutant who, early in the film, states that "we [mutants] were God's mistake", thus ends up in Eden. 
status as a hero-martyr; it opens on a much different note, depicting the former X-Man in a brutally realistic, decidedly unflattering manner. In his very first appearance, Logan is lying down, sleeping in his limo and looking very old and very ill. In the first close-up of his face, which Mangold will use liberally, we see his hair and beard, both in need of trimming, and both greying; there are deep lines around his eyes and the very first word that he utters is an expletive (the word which is also employed both liberally and fittingly throughout the film, in various grammatical forms). The expletive conveys Logan's annoyance at four Mexican men who are removing the wheels from the limo, forcing him to react. Cut to his feet: shuffling and unsteady; the following medium shot confirms that he can barely stand straight; he is moving very slowly and totteringly, as if remembering how to walk - he is either very drunk or very sick (it turns out he is both, and will remain so for the greater part of the film). But the medium shot allows the viewers to witness the familiar, still powerful figure, and the famously muscular body. Yet this body is now askew; Logan's left eye, moreover, is puffed up. When he speaks, his voice is hoarse; the attempt at verbal communication ends with him being shot in the second minute of the movie. A medium shot of Logan lying down on the ground, in his cheap, formal dark suit, with a bloody hole in the right side of his chest immediately calls to mind funeral ${ }^{18}$. Significantly, this is where that the film's title appears, and it says Logan rather than Wolverine, though it is under the latter name that Jackman's character is known both in the movieverse and in the comics. Such choice expresses the director's politics in relation to his (formerly) hypermasculine superhero, which is succinctly expressed by Kevin Jarre's instruction in the Tombstone script. Namely, describing the Earps and Doc Holliday walking through the streets of Tombstone on their way to the O. K. Corral, Jarre writes, "they look all too human and nothing like their legend". The title Logan, identifying an immobile, prostrate body in a dark suit, with the visible gunshot wound, promises that this, too, will be about the man rather than the legend. And, "in the real world, people die", as Logan himself tells Laura, criticizing her obsession with the X-Men comics. (The

18 Funerals pile up throughout the film, culminating in Logan's: it is at a funeral that Logan is approached by Gabriela; when he criticizes the X-Men comics for their unrealistic portrayal of superheroes, he is holding the issue depicting Jean Grey's funeral; Charles and Laura watch the funeral in Shane in a hotel room; the viewers also get to watch Charles being buried. 
film, of course, cannot but ultimately confirm the legend, depicting Logan as a proper hero-martyr; proving that Eden exists, and allowing both Charles and Caliban redemption.) So far, the dominant impression Logan leaves on the viewer has been that of faded masculinity, a mere ghost of the former leather-dressed muscular power (X2, X-Men 3: The Last Stand). Yet The Wolverine is still there. When the deadly mutant reappears - very slowly, growling, and literally struggling to stand on his feet - he is still hunched a little; one of the blades of his claws, moreover, does not come out fully, conveying eloquently the emasculating effect of aging and illness. Even with his adamantium claws, moreover, this Wolverine takes a lot of beating before killing three, and maiming one of the thieves.

The next scene, in which Logan cleans up in an El Paso gas station bathroom, is also worth dwelling on a bit. The scene opens with a close-up of the mutant's bloodied knuckles gripping a sink, after which the camera moves to encompass his naked upper body. With this, the reason for Logan's gripping the sink is revealed: he is pushing the bullets out of the swollen, bloody holes in his forearm and chest, gasping in pain and exertion, almost as if he is giving birth. As this is the fifth minute of the film, the childbirth association is relevant in suggesting the plot, which, centered as it is on the painful physical aspects of poverty-plagued male aging, illness, and death, is also about family and parenting. Yet, just like all the scenes in Tombstone where Doc Holliday is partly undressed, this particular scene also demonstrates that "the narrative context in which men's bodies are presented as objects of the gaze differs from the female setting" (Kord and Krimmer, 2011, p. 6) i.e. "[w]hen the Bond girl undresses, it is for sex. When Bond disrobes, he is about to be tortured" (ibid.). Throughout the film, Logan's disrobed body is indeed consistently displayed as the physical history of suffering only (though this does not mean he is not sexually objectified in another way). Having expelled the bullets from his body, with visibly shaking hands, Logan manages to put on a clean white shirt, but not before the viewers have had the opportunity to catch a glimpse of his muscular back covered in scars, the image which conveys that The Wolverine's legendary regenerative abilities have slowed down. The scene ends with Logan's looking in the mirror. Even though he is cleaned up, he looks considerably older than in the previous movies; much older, too, than Hugh Jackman at the time of filming this scene, when he was only 48 . The greying hair and beard, in particular, are far from "standard markers of 
mature masculinity" (O'Brien, 2014, p. 85): their function is to accentuate the jarring contrast between Logan and Wolverine, between the mutant superhero who belonged to the X-Men, and the impoverished, seriously ill elderly man with no medical insurance.

For the rest of the film, Logan will never stand up straight, let alone walk with a straight back. (At its very end, though, he will literally run to his death, fuelled by the overdose of the strength-enhancing serum, in the scene which employs the conventions of a superhero movie to literalize Tombstone's gap between Doc Holliday's disabled and enhanced masculinities.) He will be shown limping, dragging his legs, coughing constantly (with increasing severity), and drinking - though he buys ibuprofen illegally for Charles, he self-medicates with alcohol, just like Doc Holliday. Just like Doc Holliday, moreover, he will eventually start spitting blood. This particular harbinger of impending death appears on a white towel in a hotel bathroom, while Charles and Laura are watching Shane in the other room. Significantly, the blood-spitting coughing fit is initiated by Logan bending over to lace up his shoes. This visible proof of how ill the mutant is - he cannot even lace up his own shoes without coughing up blood - is conveyed via medium shots of Hugh Jackman's bent, half-naked, exceedingly muscular body in jeans, proving once again that the "eroticization of the male body is routinely motivated by the evidence of suffering and endurance" (Kirkham and Thumim quoted in Kord and Krimmer, 2011, p. 6). While his suffering body is not necessarily eroticized as a woman's, however, Mangold includes an early, melancholy scene, in which Logan is addressed as "hey driver!" and flashed by an attractive bridesmaid in a pink dress. A ghost of a sad smile appears on his face as he shakes his head slightly at the sight of the young woman's breasts: there is not even a hint of a healthy libido which characterized the Wolverine of the previous installments. The girl, moreover, presses a couple of dollar bills into Logan's hand upon leaving the limo, saying "You're such a doll". Like Doc Holliday, in this scene Logan is both desexualized and sexually objectified - i.e. treated like a woman - by his unmasculine age, illness, and poverty.

Yet, despite this objectification; despite the abovementioned associations with childbirth and the blood-leaking from the mouth; despite so many shots where he is lying down, surrounded by armed men who take turns forcing their hands, boots, and weapons onto his body, asserting their domination over him, Logan does not appear as feminized as Doc Holliday. One reason is that, in keeping 
with Mangold's demythologizing politics, he does not suffer prettily: he only suffers. The other is that he is not as emaciated as Doc, and the association of bulky muscles and virility is too deeply ingrained to be dismantled easily, or at all. His costume, also, plays a significant part. Unlike Doc Holliday, Logan is emphatically not elegant, though he, too, wears white. Once he drops the cheap limo driver's suit, he changes into a pair of jeans and a denim shirt, which signals Logan leaving behind his financially struggling, middle-aged identity, and approaching not only comic-book heroic masculinity, but martyrdom as well. Namely, jeans and a white sleeveless T-shirt, both of which accentuate Logan's impressive musculature, represent the outfit in which he dies. Furthermore, it is impossible to miss the behavioral patterns exhibited by normatively masculine men in Logan's conduct - the violence to which he resorts ${ }^{19}$; the alcohol on which he relies to anesthetize his anxiety and chronic pain resulting from adamantium poisoning; and, above all, the characteristically manly refusal to verbalize his very real fears. Caliban, who willingly plays the role of a housewife in their little smelting-plant-household, outlines both Logan's suffering and his unhealthy, much-needed, coping mechanisms:

“I hear you at night. You're not sleeping. You don't want to talk about that. Or the booze you're drinking or the pus you keep wiping from your knuckles or the blood I wash from your clothes or the fresh wounds in your chest, the ones that aren't healing. And I'm pretty sure you don't wanna talk about the fact that you can't read the label on the side of that bottle. It says 'Ibuprofen"'.

It is this last implicit diagnosis that provokes the most violent response, as Logan angrily slaps the mug from Caliban's hand, breaking it. Still, he starts wearing reading glasses: the price tag still attached to them, visible in one of the following scenes, conveys that these, too, are bought rather than prescribed by the doctor i.e. acquired via institutionalized channels. It might also convey that Logan's eyesight at this point is so bad that he did not even notice the price tag.

Logan's normative-masculinity-affirming behavioral patterns, however, are not exhausted with violence, drinking, and refusing to verbalize his fears. There are more positive aspects - "those gen-

19 Because he "hates guns", this violence that Logan continues to fall back on appears much more physical and primal - masculine - than Holliday's elegant application of guns and a Bowie knife. 
tler or less abrasive versions of masculinity" (Glover and Kaplan, 2009, p. 88) - which Mangold makes visible as well. Echoing Wyatt Earp's protectiveness of Doc, Logan takes care of Charles, most visibly by lifting him in his arms and carrying him several times in the film, including the final time, when Charles, mortally stabbed by $\mathrm{X} 24$, is dying in his arms. (He carries Laura, too.) There is defiance in face of a much stronger enemy - in one of the first encounters with Donald Pierce (Boyd Holbrook) and his hired men, Logan, as expected, is beaten; he falls on his back and eight heavily armed men cock their guns at him. Pierce taunts him, calling him by his former name, "Jesus, Wolverine, seeing you like this just breaks my damn heart". Logan responds by threatening to rip said heart out of Pierce's chest, and gets a boot in the face for his unapologetic, heart-warming defiance. Finally, there is something resembling pride. After the massacre at the Munson farm, slashed and stabbed by X24's claws and on his knees, Logan is held at gunpoint by the lethally wounded Will Munson (Eriq La Salle), who is driven mad by the loss of his wife and a teenage son. Without a word, Logan struggles only to stand up, more than willing to die at the hand of a friendly farmer. Standing up, still slightly hunched, he simply looks the man holding him at gunpoint in the eye, ready to receive the kind of death Doc Holliday longed for - in his boots, shot by another man. But Will Munson dies before pulling the trigger, denying Logan this proper Western death.

While Mangold's film is in its essence a Western, Logan's death is more Christ-like - that muscular Christ so beloved by Michelangelo - after extended and intense physical suffering, which the audience observes through close-ups, and hears in Jackman's growling, he dies on a tree, with a spear-like branch lodged in his side. Just like Christ who, according to Christian mythology dies out of love, Logan, too, dies in order to deliver Laura and the mutant children from evil that is Transigen Corporation. While his death might be read as the unquestionable confirmation of normative masculinity - dying in fight, dying as a father and the protector of children - it is important to note that it is Laura who kills X24, blowing his brains out with the adamantium bullet Logan has been saving for his suicide ${ }^{20}$. Logan's final task, therefore, is not so much to kill -

20 Presumably, Logan was planning to kill himself once Charles died aboard The Sunseeker: it is impossible not to read this potential subplot as a comment on contemporary neoliberal practices which effectively offer death and suicide as the only medical plan to the impoverished and the marginalized. 
arguably a more masculine action - as to die. As such, his death extends beyond normative gender conventions into, simultaneously, humanization and martyrdom.

\section{CONCLUSION: (IM)POSSIBLE MARTYRDOM}

Tombstone and Logan approach male aging, illness, and dying in two (radically) different ways. One, as I have been arguing, is to depict the previously normatively masculine/enhanced bodies of Doc Holliday and Wolverine as more or less feminized by their specific, age-related or not, illnesses and disabilities. This feminization - the representation of the sick and dying male bodies as overlapping with feminine-coded vulnerability, physical frailty, and disempowerment - in Tombstone and Logan, moreover, explicitly includes the protagonists' social marginalization, the impossibility of sustained economic independence, and sexual objectification, all of which continue to be experienced disproportionately more by women throughout the world. Though Logan, in particular, has brilliant female characters that deviate from the cultural expectations of (white) femininity, and Tombstone portrays Josephine Marcus as a free-loving, liberal-minded New Woman, it is with their representation of the feminized disabled men that the two films contribute to the cultural promotion of normative, able-bodied masculinity, and reinforce gender hierarchy.

While presenting a veritable gender analysis playground, the feminization of the male characters, on the other hand, does not explain the emotional satisfaction the viewer experiences when watching these films. This particular response, arguably, arises from the other way in which the films tackle male aging, illness, and dying - by emphatically promoting self-sacrifice and martyrdom of these men (the humanization proceeding from the former icons of heroic/normative masculinity being stripped of the attributes of male power plays a significant part as well). Seeing Holliday and Logan as martyrs is practically inevitable: whatever else we may be watching in Tombstone and Logan - the feminization of the disabled male bodies, the de- and re-mythologizing of pop culture heroes; the exciting dialogues with Shane on the nature of violent heroism; the love story between Wyatt Earp and Doc Holliday - we are also watching, for an extended period of time, male bodies in pain. And, in a culture that has been dominated for a thousand 
years by Christian mythology and iconography, "a broken, suffering, and dying male body" will inevitably echo "the heart of the Christian imaginary" (Brintnall, 2011, p. 23), which is one such body (not to mention hundreds of other, tortured, emaciated, and broken bodies of saints and martyrs with which Christian mythology is so densely populated). This is not to say, however, that the martyrdom of Doc Holliday and Logan is strictly Christian or Christ-like: as already stated, it is a pop culture version of martyrdom that coexists, comfortably, with killing. This martyrdom, moreover, has nothing to do with dying for religious belief, but with doing whatever is necessary to protect one's friends and family, including, but certainly not limited to, giving one's life. Indeed, in both films friendship and family are consistently presented as the ultimate value, while inflicting/enduring pain and dying for their sake are represented as the choices willingly made by the protagonists. In the abovementioned scene with Doctor Goodfellow, for instance, Doc Holliday is clearly presented with the options: he can live a bit longer, if he stops immediately "[his] smoking, [his] drinking, [his] gambling, [his] night life", and if he denies his "marital impulses". The decision seems to be made for Doc by Kate, who, despite the obvious evidence to the contrary, insists that she "knew it [Doc's coughing up blood and fainting] was nothing", puts a cigarette between his lips and initiates sex. Uncharitably, she is labeled as a potential "Antichrist" by Doc, who nonetheless does not say "no". But the film makes it clear - explicitly, in dialogue, and via editing - that it is Doc's decision to join his friend's Vendetta Ride that shortens his life dramatically, by exposing his ill body to the exertion of the near-constant horse riding, camping under the stars and poor diet, in addition to placing said body in the line of fire. Near the end of the film, the epic slow-motion shot of the four riders, Doc included, followed by the equally epic Bruce Broughton's "Finishing it" music theme, is transformed into Glenwood Sanatorium sign, the dissolve ${ }^{21}$ conveying emphatically that Doc rides straight into a hospital as a price for his loyalty to Wyatt Earp. (In reality, the gunfight at O.K. Corral took place in 1881; the Earp Vendetta Ride lasted from March till April 1882; Johnny Ringo was murdered in July 1882, and Doc Holliday died in a Colorado hotel in

21 "A dissolve joins two shots together by blending them, so that the end of the first shot and the beginning of the second shot are superimposed upon the screen for a period of time specified by the filmmaker to the laboratory" (Villarejo, 2006, p. 43). 
1887, unvisited by Wyatt Earp.) The visually stunning, genre-shifting Logan, too, is ultimately about the former X-Man's tortuous journey towards Eden where he will die, after protracted physical and emotional suffering, protecting the utterly exploited, including his child. Wolverine's trademark mutant strength and regenerative abilities, slowed down as they are, do not save him in this film. They only allow him to suffer much more, and for much longer, than ordinary human beings, and thus further reinforce the martyrdom associations.

Just like the representation of disabled masculinities, the pleasures and the politics of pop culture martyrdom are complex. It may be that the viewer indulges in "active sadistic voyeurism" just as Vertigo's Scottie in Laura Mulvey's famous analysis (irrespective of gender, though), and thus enjoys watching the heroes' bent, broken, and bloodied bodies on a big screen. It may be that the viewer is romantic and responds (too) emotionally to the films' manipulative addition of sanctity and heroism to the simple fact of the natural deterioration of the old/sick body - instead of, perhaps, dissecting it? Politically, this martyrdom is troubling as well: despite Logan's moments of acute socio-political commentary, the film's overall politics may well be feeding into the neoliberal offloading the responsibility of care onto the isolated, increasingly helpless individual: what greater care, after all, than dying for someone - especially when the state is not to be relied upon? Martyrdom, too, may be promoting normative gender roles, with the male-body-in-pain specifically as the ultimate redemptive figure, just as Brintnall insists. Moreover, it is difficult not to notice that, by speeding up death and embracing martyrdom, Cosmatos' Doc Holliday and Mangold's Logan are rejecting the identity of "the invalid" and a patient, perhaps sending the ableist message that death is not only manlier, but also preferable to living with illness and disability.

While every one of these issues deserves to be treated in a separate paper, at the end of this one it is only appropriate to go back to the title and the abstract. Not negating the abovementioned potential interpretations, I would argue that the pleasure and the emotional satisfaction of Tombstone and Logan are to be found in the way they offer martyrdom, ultimately, as a response to the terror of an anonymous and meaningless death. It is this terror that Hannah Arendt expressed so acutely in her examination of the Nazi concen- 
tration camps which, she claimed, made martyrdom impossible for the first time in Western history:

"The Westem world has hitherto, even in its darkest periods, granted the slain enemy the right to be remembered as a self-evident acknowledgment of the fact that we are all men (and only men). It is only because even Achilles set out for Hector's funeral, only because the most despotic governments honored the slain enemy, only because the Romans allowed the Christians to write their martyrologies, only because the Church kept its heretics alive in the memory of men, that all was not lost and never could be lost. The concentration camps, by making death itself anonymous (making it impossible to find out whether a prisoner is dead or alive) robbed death of its meaning as the end of a fulfilled life". (Arendt, 2000, p. 133)

Though Arendt was discussing a historically specific phenomenon, it is difficult not to see the postmodern, neoliberal condition in general as beset by the same threat - not only the reappearance of Nazism, but also life and death being increasingly drained of both fulfillment and meaning. Arendt's words, moreover, are curiously echoed in John Green's young adult "sick-lit" classic, The Fault in Our Stars (2012) where one of the protagonists, a seventeen-yearold boy dying from osteosarcoma, explains why he fears oblivion:

“The oblivion fear is something else, fear that I won't be able to give anything in exchange for my life. If you don't live a life in service of a greater good, you've gotta at least die a death in service of a greater good, you know? And I fear that I won't get either a life or a death that means anything". (Green, 2012, p. 166)

It is precisely a meaningful death, "a death in service of greater good" that Tombstone and Logan reward their ill/disabled protagonists with, transforming it thus from a brutal experience and a plain fact into a deeply comforting expression of love. While there are numerous details that suggest this sacrificial giving of life confirms normative masculinity as well - killing in the name of friendship, dying in fight - the considerable pleasure of Tombstone and Logan lies precisely in their loving development of the possibility of martyrdom and meaningful death, side by side with the depiction of the much less pleasurable reality of aging, illness, and dying.

REFERENCES Andras, E. (2016). Wynonna Earp.

Arendt, H. (2000). Total Domination. In P. Baehr (Ed.), The Portable Hannah Arendt (pp. 119-146). New York and London: Penguin Books. 
Brintnall, K. (2011). Ecce Homo: The Male-Body-in-Pain as Redemptive Figure. Chicago and London: University of Chicago Press.

Connell, R. W. (1995). Masculinities. Berkeley and Los Angeles: University of California Press.

Cosmatos, G. P. (1993). Tombstone.

Ford, J. (1946). My Darling Clementine.

Gates, P. (2006). Detecting Men: Masculinity and the Hollywood Detective Film. New York: State University of NY Press.

Glover, D. and Kaplan, C. (2009). Genders. London and New York: Routledge.

Green, J. (2012). The Fault in Our Stars. New York: Dutton Books.

Jarre, K. Tombstone. An Original Screenplay. http://www.dailyscript.com/scrip ts/tombstone.pdf. Accessed 9 June 2018.

Kasdan, L. (1994). Wyatt Earp.

Kord, S. and Krimmer, E. (2011). Contemporary Hollywood Masculinities: Gender, Genre and Politics. New York: Palgrave Macmillan US.

Kulchavenya E., et. al. (2017). Tuberculosis as a Reason for Male and Female Sexual Dysfunction. https://www.omicsonline.org/open-access/tubercul osis-as-a-reason-for-male-and-female-sexual-dysfunctionreview.php?aid= 92786. Accessed 17 July 2018.

Lehman, P. (2007). Running Scared: Masculinity and the Representation of the Male Body. Detroit: Wayne State University Press.

Longhurst, R. (2001). Bodies: Exploring Fluid Boundaries. London and New York: Routledge.

MacDonald, K. (2016). Film Theory: The Basics. London and New York: Routledge.

MacInnes, J. (1998). The End of Masculinity. Buckingham and Philadelphia: Open University Press.

Mangold, J. (2017). Logan.

McGann, W. (1942). Tombstone, the Town Too Tough to Die.

Mulvey, L. (1999). Visual Pleasure and Narrative Cinema. In L. Braudy and M. Cohen (Eds.), Film Theory and Criticism: Introductory Readings (pp. 833-844). New York: Oxford UP.

O'Brien, D. (2014). Classical Masculinity and the Spectacular Body on Film: The Mighty Sons of Hercules. Basingstoke: Palgrave Macmillan.

Ott, K. (1996). Fevered Lives: Tuberculosis in American Culture since 1870. Cambridge, MS and London: Harvard UP. 
Pilcher, J. and Whelehan, I. (2004). 50 Key Concepts in Gender Studies. London, Thousand Oaks and New Delhi: SAGE Publications.

Sabo, D. and Gordon, D. F. (eds.). (1995). Men's Health and Illness: Gender, Power, and the Body. Thousand Oaks, CA: SAGE Publications Inc.

Sontag, S. (2001). Illness as Metaphor and AIDS and its Metaphors. London: Picador.

Sturges, J. (1957). Gunfight at the O. K. Corral.

Sturges, J. (1967). Hour of the Gun.

Tankard, A. (2018). Tuberculosis and Disabled Identity in Nineteenth Century Literature: Invalid Lives. Basingstoke: Palgrave Macmillan.

Tennant, F. (2015). Doc Holliday: A Story of Tuberculosis, Pain, and Self-medication in the Wild West. https://www.practicalpainmanagement.com/pain /doc-holliday-story-tuberculosis-pain-self-medication-wild-west. Accessed 13 July 2018.

The Life and Legend of Wyatt Earp. (1955).

Thomas, C. (2008). Masculinity, Psychoanalysis, Straight Queer Theory. Basingstoke: Palgrave Macmillan.

Tombstone Dialogue Transcript. http://www.script-o-rama.com/movie_script s/t/tombstone-script-transcript-val-kilmer.html. Accessed 8 June 2018.

Villarejo, A. (2006). Film Studies: the Basics. London and New York: Routledge.

Wendell, S. (1996). The Rejected Body: Feminist Philosophical Reflections on Disability. New York and London: Routledge.

ДАНИЈЕЛА Љ. ПЕТКОВИЋ

УНИВЕРЗИТЕТ У НИШУ

ФИЛОЗОФСКИ ФАКУЛТЕТ

ДЕПАРТМАН ЗА ЕНГЛЕСКИ ЈЕЗИК И КњИЖЕВНОСТ

РЕЗИМЕ

(НЕ)МОГУЋЕ МУЧЕНИШТВО: МАСКУЛИНИТЕТ, СТАРЕњЕ, БОЛЕСТ И СМРТ У ФИЛМОВИМА ТУМСТОУН И ЛОГАН

Наслов рада алудира на добро познату тврдњу Хане Арент да је у нацистичким концентрационим логорима мучеништво, по први пут у историји, било онемогућено потпуном анонимношћу и обесмишљеношћу смрти логораша (Арент, 2000, стр. 133). Сам рад пак разматра два савремена филма, који, укрштајући нормативни маскулинитет са болешћу, старењем и умирањем не негирају ту могућност. Филмови Џорџа Косматоса и Џејмса Мен- 
голда, Тумст̄оун и Лоїан, приказују последње дане (поп) културних икона мужевности као што су Џон Хенри „Док“ Холидеј и Џејмс Хаулет, познатији као Логан/Вулверин. Тематско фокусирање ових филмова на завршетак живота, које је очигледно не само у заплетима и дијалозима већ и у бројним крупним плановима измршавелих, крвавих, оборених мушких тела, оболелих од туберкулозе и тровања адамантијумом, захтева, најпре, разматрање филмског приказивања нормативног маскулинитета и маскулинитета са инвалидитетом. Конкретно, пошто се нормативни маскулинитет културно одређује насупрот феминитету, те је синоним за физичку и менталну снагу, моћ и доминацију укључујући и контролу над сопственим телом - ово разматрање ће се фокусирати на то да ли и како ови филмови приказују Дока Холидеја и Вулверина као феминизиране њиховим сопственим оболелим, непослушним телима, чиме доприносе културном конструисању рода и родних разлика. Затим ће рад размотрити емотивно задовољство гледатељке које произилази из ореола мучеништва којим су умирући мушкарци награђени у овим филмовима: Холидеј и Логан не избегавају, већ убрзавају смрт зарад пријатељства, породице и заштите рањивих и маргинализованих. Док оба филма несумњиво нуде утешне фантазије о саможртвовању и смрти која враћа достојанство насупрот брутално приказаном старењу и болести, последње питање које је неопходно размотрити јесте да ли ово (не)могуће мучеништво потврђује нормативни, телесно способни и доминирајући маскулинитет.

КљУчнЕ РЕчи: болест; феминитет; инвалидитет; Лоїан; маскулинитет; мучеништво; старење; тело; тумсйоун.

Овај чланак је објављен и дистрибуира се под лиценцом Creative Commons Ауторство-Некомерцијално Међународна 4.0 (CC BY-NC 4.0 |

https://creativecommons.org/licenses/by-nc/4.0/).

This paper is published and distributed under the terms and conditions of the Creative Commons Attribution-NonCommercial International 4.0 licence (CC BY-NC 4.0 | https://creativecommons.org/licenses/by-nc/4.0/). 